\title{
Occurrence of endo and hemoparasites in Sporophila caerulescens captured in the eastern region of the state of Acre, Brazil
}

\section{Leandro Siqueira de Souza ${ }^{1 *}$ (iD Edson Guilherme ${ }^{2,4}$ Angela Maria Fortes de Andrade ${ }^{3}$ Francisco Glauco de Araújo Santos ${ }^{1,4}$}

${ }^{1}$ Laboratório de Apoio a Vida Silvestre, Universidade Federal do Acre (Ufac), 69915-900, Rio Branco, AC, Brasil. E-mail: leandrosiqueirasouza@gmail.com. *Corresponding author.

${ }^{2}$ Laboratório de Ornitológia, Universidade Federal do Acre (Ufac), Rio Branco, AC, Brasil.

${ }^{3}$ Programa em Sanidade e Produção Animal Sustentável na Amazônia Ocidental, Universidade Federal do Acre, Rio Branco (Ufac), AC, Brasil. ${ }^{4}$ Centro de Ciências Biológicas e da Natureza, Universidade Federal do Acre (Ufac), Rio Branco, AC, Brasil.

ABSTRACT: Wild animals are hosts and reservoirs to many infectious agents, often unknown to the Scientific Community, which leads to serious health implications for natural and domestic environments. We conducted this research with the objective of diagnosing the occurrence of parasites of medical and veterinary interest in "coleirinhos" captured in the eastern region of the state of Acre, Brazil. We captured the specimens in August and September of 2017 using ornithological nets at the margins of Caeté river. We visually inspected the birds to evaluate the ectoparasites. Subsequently, we collected blood through a brachial vein puncture and rested the individuals in a cloth bag for 30 minutes to collect feces, after which we released them. Results of the visual inspection to detect and identify the ectoparasites were negative. Blood samples revealed the protozoan Haemoproteus sp., and the feces revealed cysts of Entamoeba histolytica and E. coli, oocysts of coccidia and eggs of Davaineidae. Coccidia was the most prevalent (69.2\%) and abundant (34.15\%) parasite reported. Parasites diagnosed in this study can promote the emergence of secondary infections in S. caerulescens individuals or other animals that are contaminated with these etiological agents, since, when migrating through different biomes of South America, other animal species can come into contact with these agents. Key words: animal health, endoparasites, environmental health, Haemoproteus sp., migratory birds.

Ocorrência de endo e hemoparasitos em Sporophila caerulescens capturados na região leste do estado do Acre, Brasil

RESUMO: Os animais silvestres são hospedeiros e reservatórios de vários agentes infecciosos, muitas vezes desconhecidos para a comunidade científica, o que leva a sérias implicações na saúde dos ambientes naturais e domésticos. Esta pesquisa teve como objetivo diagnosticar a ocorrência de parasitos de interesse médico e veterinário em "coleirinhos" capturados no leste do Estado do Acre, Brasil. Os espécimes foram capturados nos meses de agosto e setembro de 2017 em redes ornitológicas as margens do Rio Caeté. Para a pesquisa de ectoparasitos, as aves foram inspecionadas visualmente. Após a inspeção, o sangue foi coletado por meio de punção da veia braquial e para coletas das fezes os individuos foram postos em descanso em saco de pano por 30min e depois foram soltos na natureza. As fezes, quando presentes, foram coletadas e acondicionadas em recipientes de plástico estéreis. A inspeção visual dos espécimes para detectar e identificar ectoparasitos resultou negativo. Nas amostras sanguíneas foi identificado o protozoário Haemoproteus sp.. Nas fezes foram encontrados os seguintes endoparasitos: cisto de Entamoeba histolytica e E. coli, oocisto de coccídeos e ovos de Davaineidae. Coccideos foram os endoparasitos mais prevalentes $(69,2 \%)$ e os mais abundantes (34,15\%). Os parasitos diagnosticados neste estudo podem propiciar o aparecimento de infecções secundárias nos individuos de S. caerulescens ou em outros animais que venham se contaminar com esses agentes etiológicos, pois com a migração dos mesmos, por diferentes biomas da América do Sul outras espécies de animais podem se infectar com esses agentes.

Palavras-chave: saúde animal, endoparasitos, saúde ambiental, Haemoproteus sp., aves migratórias.

\section{INTRODUCTION}

The Amazon is the Brazilian biome with the highest number of bird species and endemism. In this biome, $92 \%$ of the bird species are resident, and only $8 \%$ migrate to the Brazilian territory (SICK, 1993). There are 708 confirmed bird species only in the region of Acre, of which 78 are migratory species. Many come through Acre for a brief period, in search for food, shelter, or rest (GUILHERME, 2016).
The "coleirinhos" (Sporophila caerulescens) is one of the migrating birds that come from the south (ORTIZ \& CAPLLONCH, 2007) and land in the state of Acre (GUILHERME, 2016). This species lives in groups of six to 20 individuals in colonized anthropized areas, such as grassy vacant lots in the cities, pastures in rural areas, plantations, and natural open fields. They are present from Argentina to Bolivia and in almost all the Brazilian territory (ORTIZ \& CAPLLONCH, 2007). In the northern and 
northeastern regions of Brazil, they appear seasonally in migratory movements (ORTIZ \& CAPLLONCH, 2007; JARAMILLO, 2018).

According to FREITAS et al. (2002) the wild animals are hosts and reservoirs of many infectious agents, often unknown to the Scientific Community, which leads to serious implications for the health of natural and domestic environments, especially when there is direct contact between these animals. These researches must be constant, given that, when concerning migratory birds, we can also evaluate the dissemination of parasites from distinct environments using a single species as study subject (COSTA et al., 2010).

A few researches have demonstrated the importance of migratory birds as a host of many infectious agents that can infect the human population. Among these is the research conducted by RODRIGUES et al. (2007) on the influenza virus on human population. The authors reported that migratory birds, especially species of the Anseriformes, Passeriformes and Charadriformes orders, are natural reservoirs for this antigen and, for most species, the virus does not cause clinical disorders, but can infect domestic animals and consequently, the human population.

Several species of parasites have already been described parasitizing several groups of resident and migratory birds in virtually all geographical regions (SANTOS-PREZOTO et al., 2004; FONSECA et al., 2005). Currently, attention is drawn to the genus Plasmodium, which causes avian malaria, which until 2005 was recorded in $13.5 \%$ of the world avifauna analyzed for hemoparasites (BRUM et al., 2016).

In addition to the lack of knowledge on the biology of these etiological agents transmitted by the wild animals, another aggravating factor is the proximity of the human population to these birds. Such proximity occurs through the need of using the natural resources for subsistence, many of which are used by the animals or even are the animals themselves, generating a direct or indirect contact with possible etiological agents.

In this research, we aimed to diagnose the occurrence of parasites of medical and veterinary interest on a species of "coleirinhos" (Sporophila caerulescens) captured in the eastern region of the state of Acre, Brazil.

\section{MATERIALS AND METHODS}

Specimens of Sporophila caerulescens were captured in the "Comunidade Cuidado"
(S 0908'50.9"; W 06901'22.3") located in the Cazumbá-Iracema Extractive Reserve, situated in the center-west region of the state of Acre, in the municipality of Sena Madureira. The reserve area is part of the West Corredor of the Amazon, one of the seven large ecological corridors proposed for Brazil.

We captured 18 individuals between August and September of 2017 using ornithological nets (Mistnets) placed in the morning $(5: 00 \mathrm{~h}-12: 00 \mathrm{~h})$ and afternoon (14:00 h - 17:00 h), at the margins of Caeté river. After capturing the specimens, we identified and measured the individuals, then they were marked by the strategic feathers of the tail, for eventual recapture notification. A stool sample, when present and two blood samples were collected from each individual. Of the individuals recaptured, no new collection was performed.

We visually inspected the birds to evaluate the parasites. After inspection, we collected blood through brachial vein puncture on one of the wings after asepsis with cotton soaked in $70^{\circ}$ alcohol (MATTER et al., 2010). Immediately after, we performed two blood smears from each individual in glass laminas fixed with methanol and stained using the Giemsa (EosinMethylene Blue) and Fast Panoptic (May-GrunwaldGiemsa) methods (DE CARLI, 2001).

For collecting the feces, we maintained the individuals in cloth bags containing absorbent paper within for 20 to 30 minutes. After this period, we released the birds and conditioned the feces, when any, in sterile plastic recipients, and sent them to the Wild Life Support Laboratory of the Federal University of Acre, where the parasitological analyzes were performed.

To prepare the laminas for microscopic analysis and quantifying the number of oocyts per defecation (OoPD), we used the fecal smear examination stained with Lugol solution by light microscopy, spontaneous sedimentation and centrifugation-flotation technique (DE CARLI, 2001). After sedimentation for 12 hours, part of the sediment was placed on glass slide, added lugol and examined under light microscopy (Olympus CX40; objectives: 10x, 40x, and 100x), being used a 40x increase for the photographs. For the coccidia research the modified formaldehyde concentration technique was used, followed by staining of the smears by the modified Ziehl-Neelsen technique (LENETTE et al., 1985). The stained smears were observed under immersion microscopy. The identification of the parasites was performed according to the characteristics described by FOREYT (2005).

We classified the infection intensity in (0) negative animal; (1) animal with a low infection between 1 and 100 OoPD; (2) animal with a moderate 
infection between 101 and 500 OoPD; and (3) animal with high infection of more than 500 OoPD (VASCONCELLOS et al., 2013). For the statistical analyzes of the data, prevalence and abundance were calculated, as defined by BUSH et at. (1997).

\section{RESULTS}

Thirteen stool samples were collected. We reported parasites in $92.3 \%(n=12)$ of the collected feces samples. The endoparasite identified were: cysts of Entamoeba histolytica and E. coli, oocysts of coccidia, and eggs of Davaineidae (Figure 1).

The visual inspection of the specimens to detect and identify ectoparasite was negative, and only $22.22 \%$ (4/18) of the individuals were positive for the presence of hemoparasites, identifying the protozoan Haemoproteus sp.

Cysts of E. coli and E. histolytica were present in $16.66 \%(2 / 12)$ of the samples and eggs of the Davaineidae cestode in $50 \%(6 / 12)$. The coccidia was the most prevalent $(69.2 \%)$ and more abundant oocyte $(34.15, \mathrm{n}=13)$ among the samples analyzed (Table 1).

Of the 12 feces samples that were positive, $50 \%(\mathrm{n}=6)$ presented mixed infection, with interaction between Davaineidae and coccidia (two samples), $E$. histolytica and Davaineidae (two samples), E. coli and Davaineidae (one sample), and Davaineidae, $E$. coli, and coccidia (one sample).
Regarding the infection intensity, in 13 individuals that provided feces samples, only one $(1 / 13-7.6 \%)$ was negative for the presence of endoparasites, $76.9 \%(10 / 13)$ presented low infection, and $15.3 \%(2 / 13)$ presented moderate infection.

\section{DISCUSSION}

The presence of gastrointestinal endoparasites in the species $S$. caerulescens and other species of the Sporophila has been reported in other studies (CARVALHO-FILHO et al., 2005; CUBAS et al., 2014; SILVA et al., 2006; MARIETTOGONÇALVES et al., 2009; CARNEIRO et al., 2011; VASCONCELLOS et al., 2013; MAGALHÃESMATOS et al., 2016; BRITO et al., 2017), but the parasites Davaineidae and E. coli are recorded for the first time parasitizing the species Sporophila caerulescens in Brazil.

The presence of E. histolytica and E. coli concerns since they are parasites of public health interest and pathogens of human intestines. Human infection can occur by respiration when aspirating dust from areas contaminated by dry feces, or by ingesting dust or food contaminated with bird feces (SILVA \& CAPUANO, 2008; COURA, 2015).

These birds are commonly reared in cages and the contact with the feces when cleaning the cages can represent another form for human infection

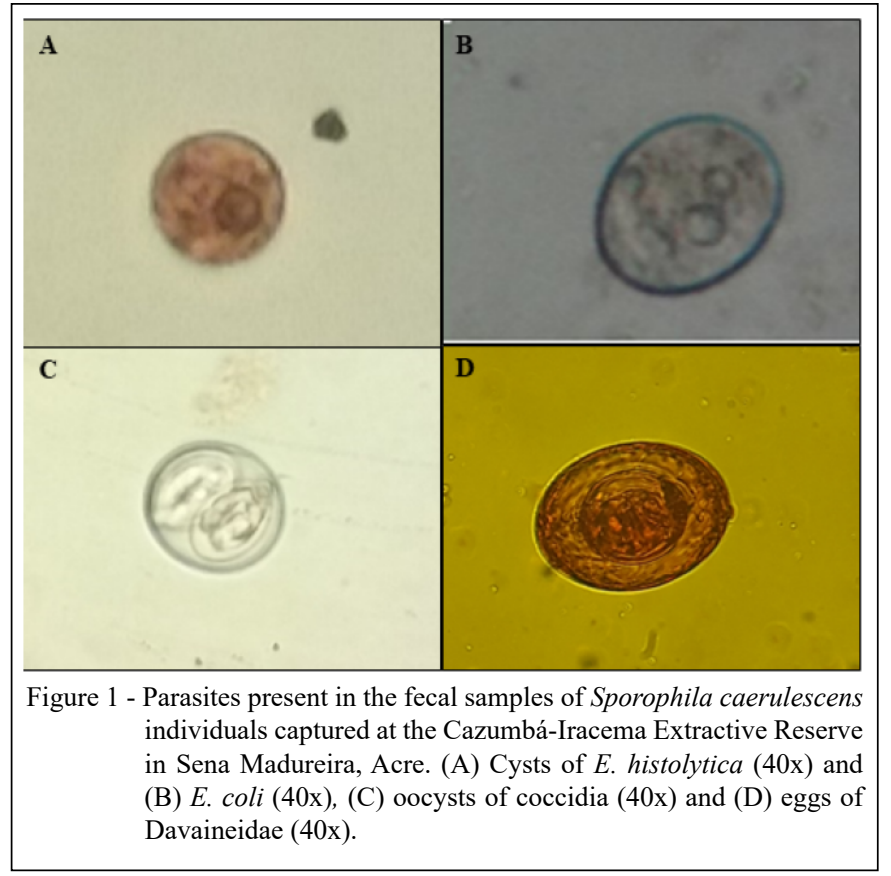

Ciência Rural, v.49, n.4, 2019. 
Table 1 - Endoparasites present in the samples of faces of the Sporophila caerulescens captured in the CazumbáIracema Extractive Reserve in Sena Madureira, Acre, Brazil. PS - positive samples, CS - collected samples, $\mathrm{P}$ - prevalence, and $\mathrm{A}$ - abundance.

\begin{tabular}{lccc}
\hline Endoparasites & PS/CS & P & A \\
\hline Protozoa & & & \\
Entamoeba histolytica & $02 / 13$ & $15.3 \%$ & 1.07 \\
E. coli & $02 / 13$ & $15.3 \%$ & 0.92 \\
Coccidia & $09 / 13$ & $69.2 \%$ & 34.15 \\
Cestodes & & & \\
Davaineidae & $06 / 13$ & $46.1 \%$ & 3.23 \\
\hline
\end{tabular}

since the extractive agents often do not sanitize the food or hands before eating. This favors the transmission of these parasites, increasing chances of environmental contamination, disease dissemination, and propagation of these etiological agents (SILVA \& CAPUANO, 2008), given that we captured the individuals close to locations that extractive agents use for cultivating watermelon (Citrullus lanatus) and corn (Zea mays).

BRITO et al. (2017) analyzed the endoparasites of wild birds of free life in the Campus and PZ of UFAC in the state of Acre, diagnosed the presence of Davaineidae (Raillietina sp.) in two species (Columbina talpacoti and Turdus ignobilis); however, for $S$. caerulescens this is the first record for the state.

MARIETTO-GONÇALVES et al. (2009) reported the presence of coccidians parasitizing the species $S$. caerulescens and $S$. nigricollis when analyzing fecal samples of wild and exotic birds in Botocatu, SP. In addition to these records mortality caused by the coccidia has been described for the Sporophila species (VASCONCELOS et al., 2012). According to the authors two $S$. maximilliani individuals died in captivity due to the high infestation by coccidia. In "bicudos" (S. maximiliani) and "curiós" (S. angolensis), we found reports of outbreaks and mortality of young between two and three months of age caused by coccidia (CUBAS et al., 2014).

The infection caused by coccidia, manifest through diarrhea, apathy, egg drop decrease, and weight loss, which can lead to the death of the infected birds, especially the young ones (JÚNIOR et al., 2000; CUBAS et al., 2014). This is concerning to the researched specimens and other species that are infected with these parasites, given that the coccidia infect all classes of vertebrates, are easily transmitted with the host's ingestion of sporulated oocyts (PAGE \& HADDAD, 1995; FRIEND \& FRANSON, 1999; LOPEZ et al., 2007; YABSLEY, 2008).

Recently in Brazil, three species of Isospora (Isospora curio, I. braziliensis, and I. paranaenses) were reported in "curiós" (S. angolensis) (SILVA et al., 2006). In "coleirinhos" ( $S$. caerulescens) three other species of Isospora were described in the eastern region of Brazil: Isospora sporophilae, I. flausinoi and I. teixeirafilhoi (CARVALHO-FILHO et al., 2005).

Among the blood parasites most common in birds, the genres Plasmodium and Haemoproteus are the most frequent, with more than 200 species of this hemoparasite being described based on morphology in 4,000 studies bird species (VALKIUNAS, 2005), results that corroborated those reported in this research.

According to BENSCH et al. (2000) the infections by hemoparasited lead to severe problems for the host, especially if native bird species are exposed for the first time. At the beginning of the $20^{\text {th }}$ century, the introduction of a new species of Plasmodium resulted in the extinction of birds native to Hawai, demonstrating the devastating effect of invasive disease (DASZAK et al., 2000; DOBSON \& FOUFOPOULOS, 2001; HARVELL et al., 2000).

None of the evaluated animals presented clinical signs suggested any pathological change, and low values of infection indicators can be explained by the fact that parasitic infections do not generally manifest clinically under natural conditions given the balance between parasite and host populations. In addition, coccidian-infected birds develop a solid immunity that protects them against subsequent infections (GALHA et al., 2008). The main form of immunity involved in protection is cellular, mainly played by $\mathrm{T}$ cells in the nucleus of the intestinal group (GALT), since GALT has an immune function and triggering effector responses, but immunity does not expand cell invasion by schizonts, only development of the schizonts in the interior, delaying the infection (DIETERT et al., 1994; LILLEHOJ, 1999; GALHA et al., 2008).

However, according to DUARTE (1997) who gathered conditions that aid in controlling host resistance, such as malnutrition and intercurrent diseases, this balance can be altered in favor of the parasite, which can cause problems to the researched species or other species that occupy the same locations in which this species forages or pass during their migratory period due to dispersion and contamination.

According to FIGUEIREDO et al. (2010) parasitological studies using wild animals, especially migratory birds, as studied species, contribute to the knowledge on parasite fauna and aid in remedying 
questions on the different parasite species from distinct environments. These studies assisted in prophylactic measures that care for the sanity of these animals and the prevention of zoonoses present in distinct environments, and that can be disseminated by hosts often unknown to the scientific community.

\section{CONCLUSION}

Passeriform birds of the species $S$. caerulescens captured in the Extractive Reserve of Cazumbá-Iracema, State of Acre, presented parasitism by hemoparasite, intestinal helminths and protozoan, with a predominance of infection with coccidia.

\section{BIOETHICS AND BIOSSECURITY COMMITTEE APPROVAL}

This research was evaluated and approved by the Biodiversity Authorization and Information System - SISBIO $\mathrm{n}^{\circ} 67436297$ and Animal Use Ethics Committee of the Federal University of Acre n⿳0 2107.009788/2016-01.

\section{ACKNOWLEDGEMENTS}

The authors thank the residents of the CazumbáIracema Extractive Reserve (Resex) for their support during the capture of the birds used in our research, the support of the Chico Mendes Institute for Biodiversity Conservation (ICMBio) and the National Council of Scientific and Technological Development (CNPq) for the scientific initiation grant.

\section{DECLARATION OF CONFLICT OF INTERESTS}

The authors declare no conflict of interest. The founding sponsors had no role in the design of the study; in the collection, analyses, or interpretation of data; in the writing of the manuscript, and in the decision to publish the results.

\section{AUTHORS' CONTRIBUTIONS}

All authors contributed equally to the design and writing of the manuscript. All authors critically reviewed the manuscript and approved the final version.

\section{REFERENCES}

YABSLEY, M.J. Eimeria. In: ATKINSON, C.T.; THOMAS, N.J.; HUNTER, D.B. Parasitic diseases of wild birds. Ames: WileyBlackwell, 2008. Cap.8, p.162-180.

BENSCH, S. et al. Host specificity in avian blood parasites: A study of Plasmodium and Haemoproteus mitochondrial DNA amplified from birds. Proceedings of the Royal Society of London, v.267, p.1583-1589, 2000. Available from: <https://www.ncbi.nlm.nih.gov/ pmc/articles/PMC1690711/pdf/11007335.pdf > . Accessed: Mar. 18, 2017. doi: 10.1098 / rspb.2000.1181.
BRITO, A.S.A. et al. Endoparasites of wild birds from Campus area and Zoobotanical Park, at the Federal University of Acre, Rio BrancoAcre. Arquivos de Ciência Veterinária e Zoologia, v.20, p.117-122, 2017. Available from: $<$ http://revistas.unipar.br/index.php/veterinaria/ article/viewFile/6363/3538>. Accessed: Mar. 18, 2018.

BRUM, W. M. et al. Parasitism in resident and migratory wild birds of Marambaia Island, State of Rio de Janeiro. Pesquisa Veterinaria Brasileira, v.36, p.1101-1108, 2016. Available from: $<$ http://www. scielo.br/pdf/pvb/v36n11/1678-5150-pvb-36-11-01101.pdf $>$. Accessed: Nov. 20, 2018.

BUSH, A.O. et al. Parasitology meets ecology on its own terms: Margolis et al. Revisited. Journal of Parasitol, v.83: 575-583, 1997. Available from: <https://www.ncbi.nlm.nih.gov/pubmed/9267395>. Accessed: Jan. 08, 2019.

CARNEIRO, M.B. et al. Coproparasitological and clinical evaluation of wild and exotic birds kept in private farms in the municipality of Alegre-ES. Ciência Animal Brasileira, v.12, p.525-529, 2011. Available from: <file:///C:/Users/leand/ Downloads/6821-64090-2-PB.pdf>. Accessed: Nov. 28, 2017.

CARVALHO-FILHO, P.R.C. et al. Three new species of Isospora Schneider, 1881 (Apicomplexa: Eimeriidae) from the doublecollared seed eater, Sporophila caerulescens (Passeriformes: Emberizidae), from Eastern Brazil, Memorias do Instituto Oswaldo Cruz, v.100, p.151-154, 2005. Available from: $<$ http://www.scielo. br/pdf/mioc/v100n2/v100n2a07.pdf >. Accessed: Dec. 28, 2017. doi: 10.1590/S0074-02762005000200007.

COSTA, I.A. et al. Ocorrência de parasitos gastrintestinais em aves silvestres no município de Seropédica, Rio de Janeiro, Brasil. Ciencia Animal Brasileira, v.11, p.914-922, 2010. Available from: <file://C:/Users/leand/Downloads/7164-50467-2-PB\%20(2).pdf>. Accessed: Dec. 28, 2017. doi: 10.5216/cab.v11i4.7164.

COURA, J.R. Dinâmica das Doenças Infecciosas e Parasitárias. Rio de Janeiro: Guanabara Koogan, 2015. 2080p.

CUBAS, Z.S. et al. Tratado de Animais Selvagens. São Paulo: Roca, 2014. 2512p.

DASZAK, P. et al. Emerging infectious diseases of wildlife threats to biodiversity and human health. Science, v.287, p.443-448, 2000. Available from: <https://www.ecohealthalliance.org/wpcontent/uploads/2016/06/Daszak-et-al_EID_Science-2000.pdf $>$. Accessed: Dec. 28, 2017.

DE CARLI, G.A. Parasitologia Clínica: seleção de métodos e técnicas de laboratório para o diagnóstico das parasitoses humanas. São Paulo: Atheneu, 2001. 980p.

DIETERT, R.R. et al. Environment-imune interactions. Poult Sci, v.73, p.1062-76, 1994. Available from: <https://www.ncbi.nlm.nih. gov/pubmed/7937467>. Accessed: Nov. 10, 2018.

DOBSON, A.; FOUFOPOULOS, J. Emerging infectious pathogens of wildlife. Philosophical Transactions of the Royal Society, v.356, p.1001-1012, 2001. Available from: $<$ https://www.ecohealthalliance. org/wp-content/uploads/2016/06/Daszak-et-al_EID_Science-2000. pdf $>$. Accessed: Dec. 28, 2017. doi: 10.1098/rstb.2001.0900.

DUARTE, J.M.B. Biologia e conservação de cervídeos sulamericanos: Blastocerus, Ozotocerus e Mazama. Jaboticabal: FUNEP, 1997, 239p. 
FIGUEIREDO, M.A.P. et al. Ectoparasitos de animais silvestres no Maranhão. Pesquisa Veterinaria Brasileira, v.11, p.988-990, 2010. Available from: <http://www.scielo.br/pdf/pvb/v30n11/ v30n11a13.pdf>. Accessed: Sep. 12, 2017.

FONSECA, A.H. et al. Borreliose de Lyme simile: uma doença emergente e relevante para a dermatologia no Brasil. Anais do Congresso Brasileiro de Dermatologia, v.80, p.171-178, 2005. Available from: <www.scielo.br/pdf/abd/v80n2/a08v80n02.pdf>. Accessed: Sep. 12, 2017.

FOREYT, W.J. Parasitologia Veterinária: manual de referência São Paulo: Roca, 2005. 248p.

FREITAS, M.F.L. et al. Parasitos gastrointestinales de aves silvestres em cautiverio em El estado de Pernambuco, Brasil. Parasitologia Latinoamericana, v.57, p.50-54, 2002. Available from: <https:// scielo.conicyt.cl/pdf/parasitol/v57n1-2/art12.pdf > . Accessed: Aug. 10, 2017. doi: 10.4067/S0717-77122002000100012.

FRIEND, M.; FRANSON, J.C. Field manual of wildlife diseases: general field and procedures and diseases of birds. Washington: Biological Resources Division, 1999. 175p.

GALHA, V. et al.. Relação entre imunossupressão e coccidiose clínica em frangos de corte criados comercialmente. Revista do Instituto de Ciências da Saúde, v.26, p.432-437. 2008. Available from: <https://www.unip.br/presencial/comunicacao/publicacoes/ ics/edicoes/2008>. Accessed: Nov. 10, 2018

GUILHERME, E. Aves do Acre. Rio Branco: Edufac, 2016. 897p.

JARAMILLO, A Double-collared Seedeater (Sporophila caerulescens). In: HANDBOOK OF THE BIRDS OF THE WORLD ALIVE, 2018, Lynx Edicions, Barcelona. Available from: $<$ https://www.hbw.com/node/62121>. Accessed: May, 19, 2018.

JÚNIOR, A.B.; MACARI, M. Doenças das aves. Campinas: Facta, 2000. 1104p.

LENETTE, E.H. et al. Manual of Clinical Microbiology Washington: American Society for Microbiology, 1985. 1384p.

LILLEHOJ, H.S. Imunologia em coccidiose aviária. In: ANAIS DO SIMPÓSIO INTERNACIONAL SOBRE COCCIDIOSE AVIÁRIA; 1999; Foz do Iguaçu. p.23-33.

LOPEZ, G. et al. Time of day, age and feeding habits influence coccidian oocyst shedding in wild passerines. International Journal for Parasitology, v.37, 559-564, 2007. Available from: $<$ https://www.ncbi.nlm.nih.gov/pubmed/17289051>. Accessed: Aug. 10, 2017. doi: 10.1016/j.ijpara.2006.12.014.

MAGALHÃES-MATOS, P.C. et al. Ocorrência de ovos e oocistos de parasitos gastrointestinais em aves Passeriformes mantidas em cativeiro no estado do Pará, Brasil. Ciencia Rural, v.46, p.21772181, 2016. Available from: <http://repositorio.ufpa.br/jspui/ bitstream/2011/8663/1/Artigo_OccurrenceEggsOocysts.pdf $>$. Accessed: Aug. 05, 2017.

MARIETTO-GONCCALVES, A. et al. Prevalência de endoparasitas em amostras fecais de aves silvestres e exóticas examinadas no Laboratório de Ornitopatologia e no Laboratório de Enfermidades Parasitárias da FMVZ-UNESP/Botucatu-SP. Ciencia Animal Brasileira, v.10, p.349-
354, 2009. Available from: <https://www.revistas.ufg.br/vet/article/ viewFile/1300/4605>. Accessed: Aug. 05, 2017.

MATTER, S.V. et al. Ornitologia e Conservação: Ciência Aplicada, Técnicas de Pesquisa e Levantamento. Rio de Janeiro: Technical Books, 2010. 516p.

PAGE, C.D.; HADDAD, K. Coccidial infections in Birds. Seminars in Avian and Exotic Pet Medicine, v.4, p.138-144. 1995. Available from: <https://www.sciencedirect.com/science/ article/pii/S1055937X05800386>. Accessed: Aug. 05, 2017. doi: 10.1016/S1055-937X(05)80038-6

ORTIZ, D.; CAPLLONCH, P. Distribución y migración de Sporophila c. caerulescens em Sudamérica. Revista Brasileira de Ornitologia, v.15, p.377-385. 2007. Available from: <http:// www4.museugoeldi.br/revistabrornito/revista/index.php/BJO/ article/viewFile/3004/pdf_470>. Accessed: Aug. 05, 2017.

RODRIGUES, B.F. et al. Vírus influenza e o organismo humano. Revista APS, v.10, p.210-216, 2007. Available from: <http://www. ufjf.br/nates/files/2009/12/13virus.pdf>. Accessed: Jun. 05, 2017.

SANTOS-PREZOTO, H.H. et al. Prevalence and variation of erythrocytic stages of Plasmodium (Novyella) juxtanucleare in Gallus gallus under natural conditions, within one year. Parasitologia Latinoamericana, v.59, p.14-20, 2004. Available from: $<$ https://scielo.conicyt.cl/scielo.php?script=sci arttext\&pid $=$ S0717-77122004000100003 $>$. Accessed: Nov. 12, 2018.

SICK, H. Ornitologia Brasileira. Rio de Janeiro: Nova Fronteira, 1993. 912p.

SILVA, E.A.T. et al. Three new species of Isospora Schneider, 1881 (Apicomplexa: Eimeriidae) from the lesser seed-finch, Oryzoborus angolensis (Passeriformes: Emberizidae) from Brazil. Memorias do Instituto Oswaldo Cruz, v.101, p.573-576, 2006. Available from: <http://www.scielo.br/pdf/mioc/v101n5/ v101n5a16.pdf>. Accessed: Sep. 05, 2017. doi: 10.1590/S007402762006000500016 .

SILVA, J.O.; CAPUANO, D.M. Ocorrência de Cryptococcus spp. e de parasitas de interesse em saúde pública, nos excretas de pombos na cidade de Ribeirão Preto, São Paulo, Brasil. Revista do Instituto Adolfo Lutz, v.67, p.137-141, 2008. Available from: $<$ http://periodicos.ses.sp.bvs.br/pdf/rial/v67n2/a09v67n2.pdf $>$. Accessed: Sep. 05, 2017.

VALKIUNAS, G. Avian Malaria Parasites and Other Haemosporidia. USA: CRC Press, 2005. 946p.

VASCONCELLOS, M.S.D. et al. Intensidade de infecção por Isospora spp. (Apicomplexa: Eimeriidae) em trinca-ferrosverdadeiros Saltator similis d'Orbigny, Lafresnaye (Passeriformes: Cardinalidae) mantidos em cativeiro no Municípiode Valença, Estado do Rio de Janeiro, Brasil. Coccidia, v.1, p.39-43, 2013. Available from: <http://r1.ufrrj.br/lcc/Coccidia/vol/v1n2/p39-43. pdf $>$. Accessed: Sep. 30, 2017.

VASCONCELOS, T.C.B. et al. Coccidiose em Sporophila maximiliani (Passeriformes: Emberizidae): relato de dois casos. Revista Brasileira de Medicina Veterinaria, v.34, p.261-264, 2012. Available from: <file:///C:/Users/leand/Downloads/21-122012_09-08RBMV001\%20(1).pdf>.Accessed: Oct. 30, 2017. 